\title{
Sedimentary Environment and Relative Sea Level Changes of the Asmari Formation Deposited in Lurestan Basin, Southwest of Zagros
}

\author{
Ava Alizadeh1, Davood Jahani', Mohammad Reza Kamali' \\ ${ }^{1}$ Geology Department, Islamic Azad University, North Tehran, Iran \\ ${ }^{2}$ Research Institute of Petroleum Industry (RIPI), NIOC, Tehran, Iran \\ Email: jahani_davood@yahoo.com
}

How to cite this paper: Alizadeh, A., Jahani, D. and Kamali, M.R. (2017) Sedimentary Environment and Relative Sea Level Changes of the Asmari Formation Deposited in Lurestan Basin, Southwest of Zagros. Open Journal of Geology, 7, 945-964. https://doi.org/10.4236/ojg.2017.77064

Received: June 19, 2017

Accepted: July 15, 2017

Published: July 18, 2017

Copyright (๑) 2017 by authors and Scientific Research Publishing Inc. This work is licensed under the Creative Commons Attribution International License (CC BY 4.0).

http://creativecommons.org/licenses/by/4.0/ (c) (†) Open Access

\begin{abstract}
Asmari Formation is deposited in the Zagros Foreland basin during OligoMiocene time. In the presented research, Sheykh Makan (north of Kabir-Kuh Anticline) section located at Lurestan Basin is studied to achieve an understanding of facies changes, paleoenvironment and also sequence stratigraphic framework (relative sea level changes) of the Asmari Formation. Results of this study revealed that 15 microfacies grouped to four facies belts named as tidal flat, lagoon, barrier and open marine are the main constituents. A homoclinal ramp is determined as the depositional setting of the Asmari Formation. In Sheykh Makan Section, studied interval contains three third-order sequences aging oligmiocene. It overlies gradually shaly Pabdeh Formation and is overlain by evaporitic Gachsaran Formatin.
\end{abstract}

\section{Keywords}

Asmari Formation, Oligomicene, Microfacies, Sequence Stratigraphic, Lurestan Basin, Southwest of Zagros

\section{Introduction}

Reservoir geologists and engineers consider that the Asmari Formation is as the first carbonate reservoir rock in the world and one the most important petroleum bearing successions of Iran. It is the most prolific formation in the southwest of Iran and contains two geologic members: Ahwaz Sandstone Member expanded in the south of Dezful Embayment and evaporitic Kalhor Member deposited in the northwestern sections of Dezful Embayment and southwest of 
Lurestan Basin [1] (Figure 1). Asmari sediments are regarded as the last transgression phase in the Zagros Region [2] documented the first study on the Asmari Formation. [3] proposed 5 biostratigraphic segments for all the Zagros formations. Biostratigraphic characteristics of Asmari are revised and three assemblage zones and two subzones are introduced by [4]. [5] revised the biostratigraphy of the Asmari Foemation using strontium isotope. [6] also proposed new biozones for Asmari. The Asmari Formation in Oligo-Miocene, with its extensive expansion in the Zagros Basin, is one of the important lithostratigraphic units in southern Iran (Dezful embayment, Lurestan and Fars basins) to northern Iraq. The existence of a highly developed joint system has led to the specific hydraulic properties of this formation and the formation of large hydrocarbon fields, which can play a significant role in identifying hydrocarbon reservoirs that have not yet been explored.

Depositional facies, secondary changes (i.e. diagenetic alterations) and sequence stratigraphic units control the external geometry (body) and internal architecture of both carbonate and silisiclastic reservoirs [6] [7] and [8]. About the first factor, reservoir quality is directly influenced by deposited facies traits (acting in fine scale) and/or sedimentary environments (acting in large scale). Diagenetic processes may also be influenced efficiently from primary early essence of the deposited units, so diagenetic history trend is potentially affected by the depositional characteristics [9]. The main output of sequence stratigraphy can be addressed as achieving a genetic framework used for correlation [10] [11] and [12]. Distinguishing the primary deposited microfacies of Asmari and their relevant facies beslts and depositional setting can be named as the first contribution of presented research. Then, presenting the genetic sequence stratigraphic framework applicable in Lurestan Basing is the second aim. Out nest attempt is interpreting the evolution (structural and depositiona) of Lurestan Basin during Asmari depositon (oligomiocene) to pave the way for more reliable exploration and drillings.

\section{Geological Setting}

Sedimentary and structural complexities of Iranian Plateau resulted in dividing it to several regions such as Zagros, Central Iran, Sanandaj-Sirjan, Alborz, eastern flish basin, Kopeh dagh, southern Khazar, Makran and Zabol Embayment [13]. Consdition of paleo-environment setting, litho-bio facies varities in coexisting formations of different regions, structural changes and their effects and

\begin{tabular}{|c|c|c|c|c|c|c|}
\hline 觉 & EPOCH & \multirow{2}{*}{ STAGE } & \multirow{2}{*}{ IRAQ } & SOUTH WEST IRAN & \multirow{2}{*}{$\begin{array}{c}\text { KUWAIT } \\
\text { and SE IRAQ }\end{array}$} & $\begin{array}{l}\text { SAUDI } \\
\text { ARABIA }\end{array}$ \\
\hline \multirow{8}{*}{$\begin{array}{l}\grave{\alpha} \\
<\end{array}$} & & & & \begin{tabular}{l|l} 
LURESTAN & KHUZESTAN \\
BAKHTYARI
\end{tabular} & & \\
\hline & PLIOCENE & & UPPER FARS & AGHA JARI & DIBDIBEA & HOFUF \\
\hline & MIOCENE & & LOWER FARS & GACHSARAN & LOWER FARS & DAM ? \\
\hline & & & JERIBE & ASMARI 1111 & GHAR & HADRUKH \\
\hline & OLIGOCENE & & KIRKUK GROUP & & & \\
\hline & EOCENE & UPPER & -JADDALA & PABDEH & DАบми & गิ \\
\hline & & LOWER & & I TALEH & RUS & RUS \\
\hline & PALEOCENE & & & $\sum \overrightarrow{A M R A N} \geq$ & RADHUMA & RADHUMA \\
\hline
\end{tabular}

Figure 1. Asmari Formation distribution during Cenozoic in southwest of Iran [1]. 
especially evidence of the paleotethys and neotethys sutures also play an influential role in segmenting this huge plateau [13] and [14]. Southern Iran is devoted to the area southwest of neotethys suture embracing Khuzestan, Lurestan and Fars. This area is placed in the northeastern of Arabian Palte. The gigantic plate comprises Arabian countries such as Saudi Arabia, Jordan, Syria, and Iraq [15] (Figure 2). The Zagros area is divided into three tectonic zones from northeast to southwest: the High Zagros (Zone of tectonic activity), the Zagros simply folded belt and the Zagros foredeep zone [16]. The Zagros simply folded belt is subdivided according to its tectonic and sedimentary evolution into three domains: Lurestan, Izeh and Fars areas [17] (Figure 3).

Section Sheykh Makan is located in the northern limb of Kabir Kub Anticline and south of Sheykh Makan village belonging to Illam Province (Figure 4(a)). The access to the area is available in the road of Poldokhtar to Dareh Shahr cities.

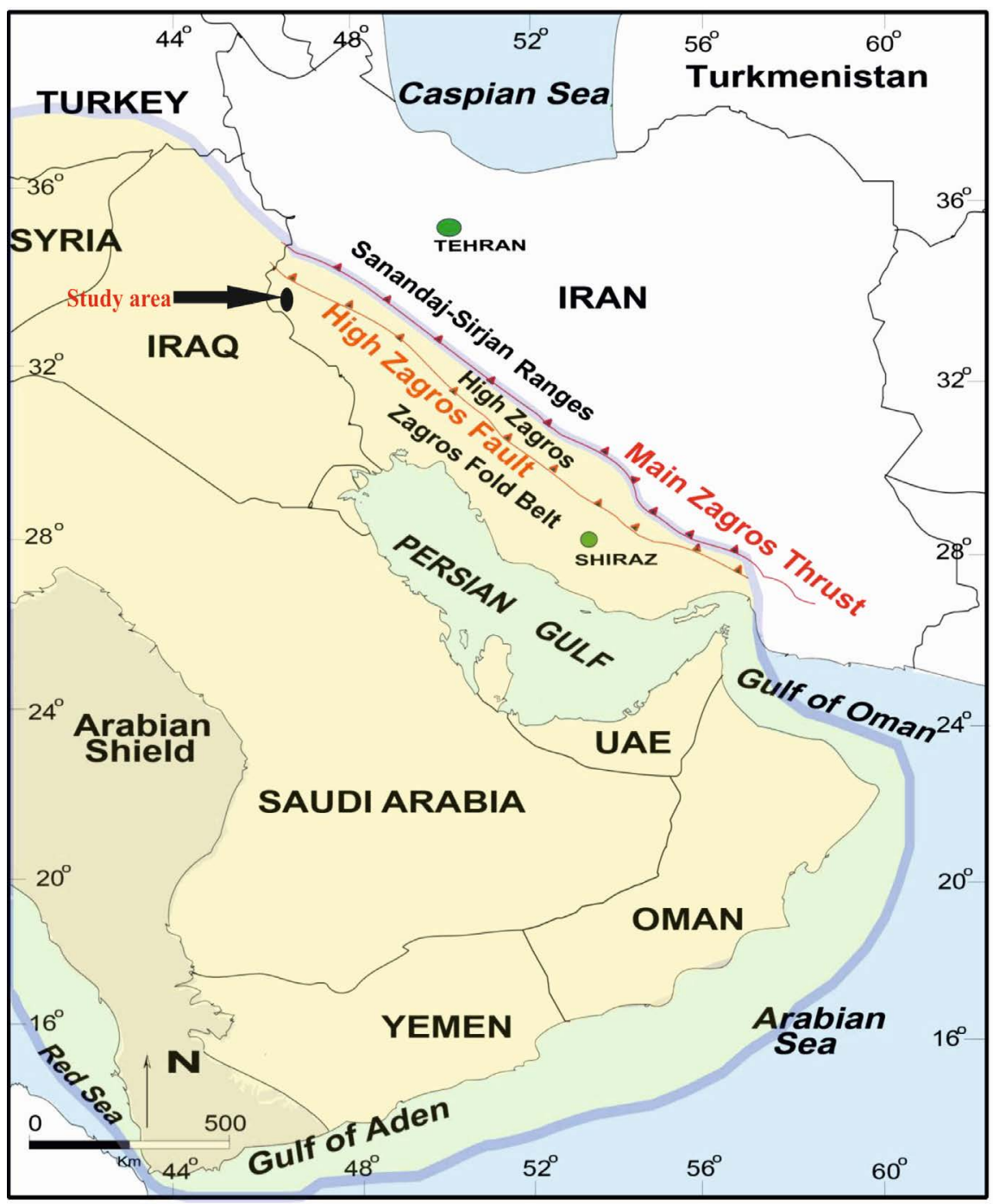

Figure 2. The Zagros area located in the northeastern part of the Arabian Plate. The Arabian plate comprises the Arabian Peninsula together with Jordan, Syria and Iraq. A Zagros crush zones bound the plate to the northeast, and is bounded by Arabian Sea and Gulf of Aden to the southeast, and by the Red sea to southwest [15]. 


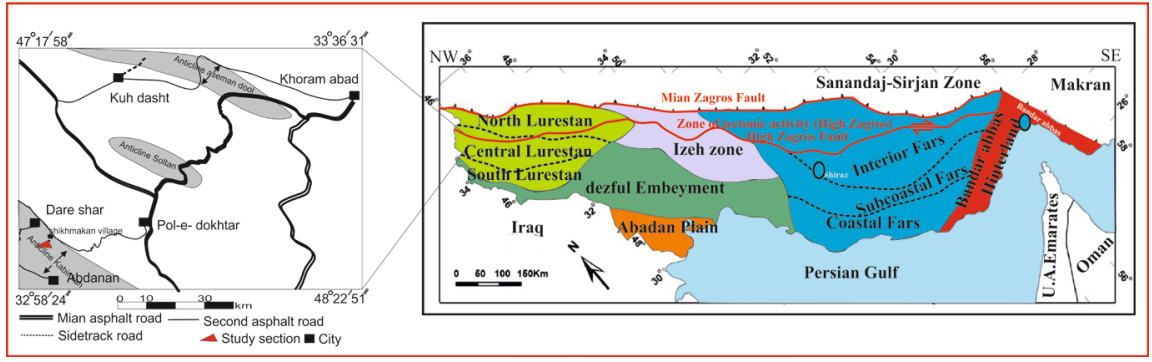

Figure 3. Tectonic zones of the Zagros area [17] and locations of the surface section. The Zagros area is divided into three tectonic zones from northeast to southwest: the High Zagros (Zone of tectonic activity), the Zagros simply folded belt and the Zagros foredeep zone [16]. The Zagros simply folded belt is subdivided according to its tectonic and sedimentary evolution into three domains: Lurestan, Izeh and Fars areas [17]. The Fars area is separated into four sectors: coastal, subcoastal, interior Fars and Bandar Abbas Hinterland
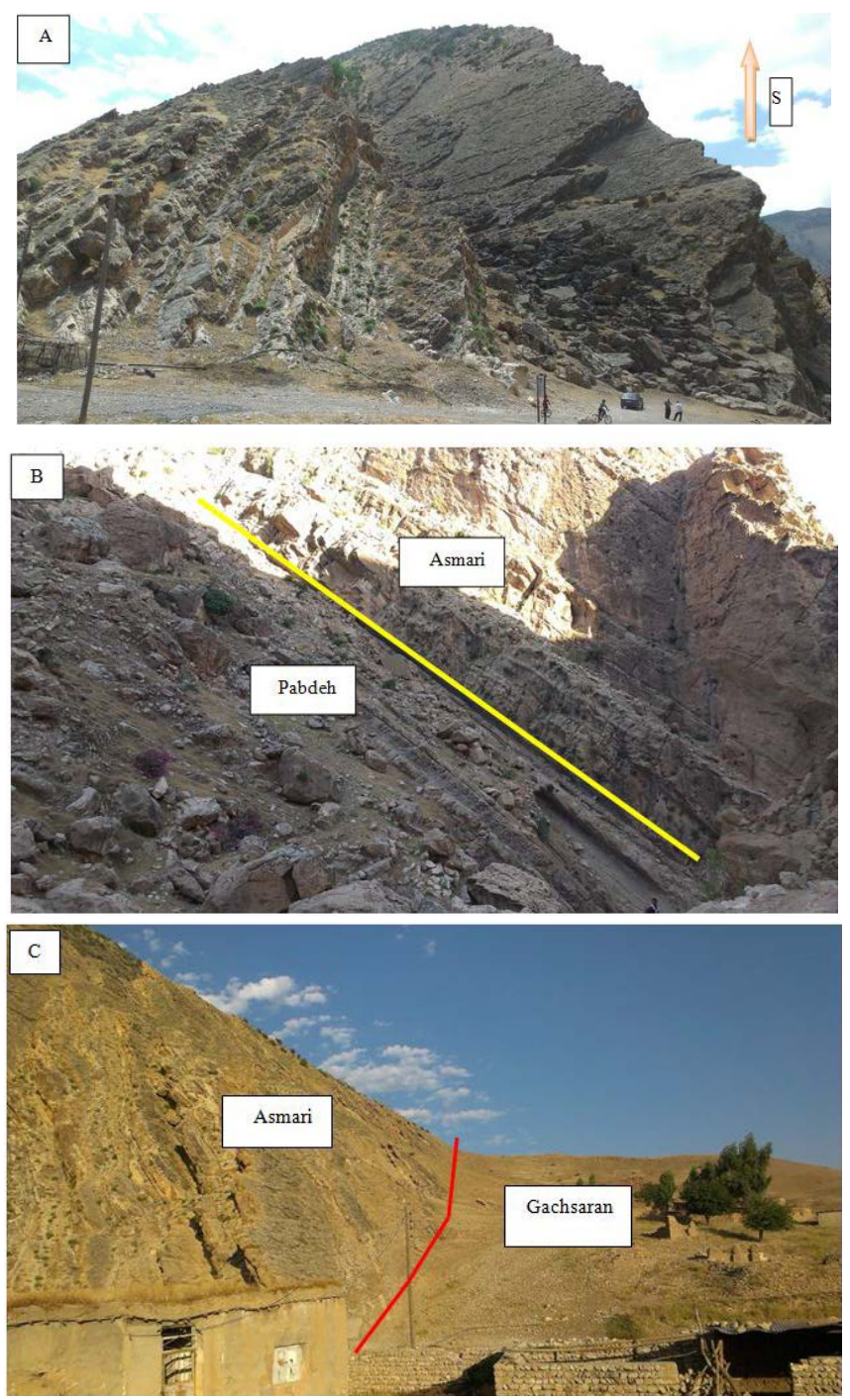

Figure 4. (a) A view of Sheykh Makan Section in the south of picture; (b) Lower contact of Asmari formation with Pabdeh formation in the Sheykh Makan Section; (c) Gachsaran formation overlying Asmari formation in Sheykh Makan. 
Asmari succession thickness is 200 meters composing of layered limestone, massive dolomitic limestone, marn with limestone layers, and sandy limestone Shale to marl bearing Pabdel Formation is overlaind gradually and conformably by Asmari in this section (Figure 4(b)). In this section, Gachsaran Formation is observed ate the upper boundary sharply and conformably (Figure 4(c)).

\section{Materials and Method}

To depict the depositional setting and sedimentary sequences of Asmari in two sections, 150 thin sections are prepared and studied. These slides are prepared from the mentioned sections. A detailed field observation is carried out to achieve a deeper understanding of the facies distribution. [18] updated textural classification presented by [19] and their result is exerted to name the distinguished microfacies and also their depositional setting is compared to Flugel introduced standard ramp microfacies (RMF) [20] System tracts of sequences are defined by tracing two main surfaces (maximum flooding surface (MFS) and sequence boundary (SB)) and Arabian Plate sequences [21] and also universal sequences [22] are compared to results of this study.

\section{Biostratigraphy}

Strontium isotope dating method is handled to detect the age of Asmari (Figure 5). According to this approach, Asmari Formation is divided to three assemblage and one obscure zones including lower, middle and upper.

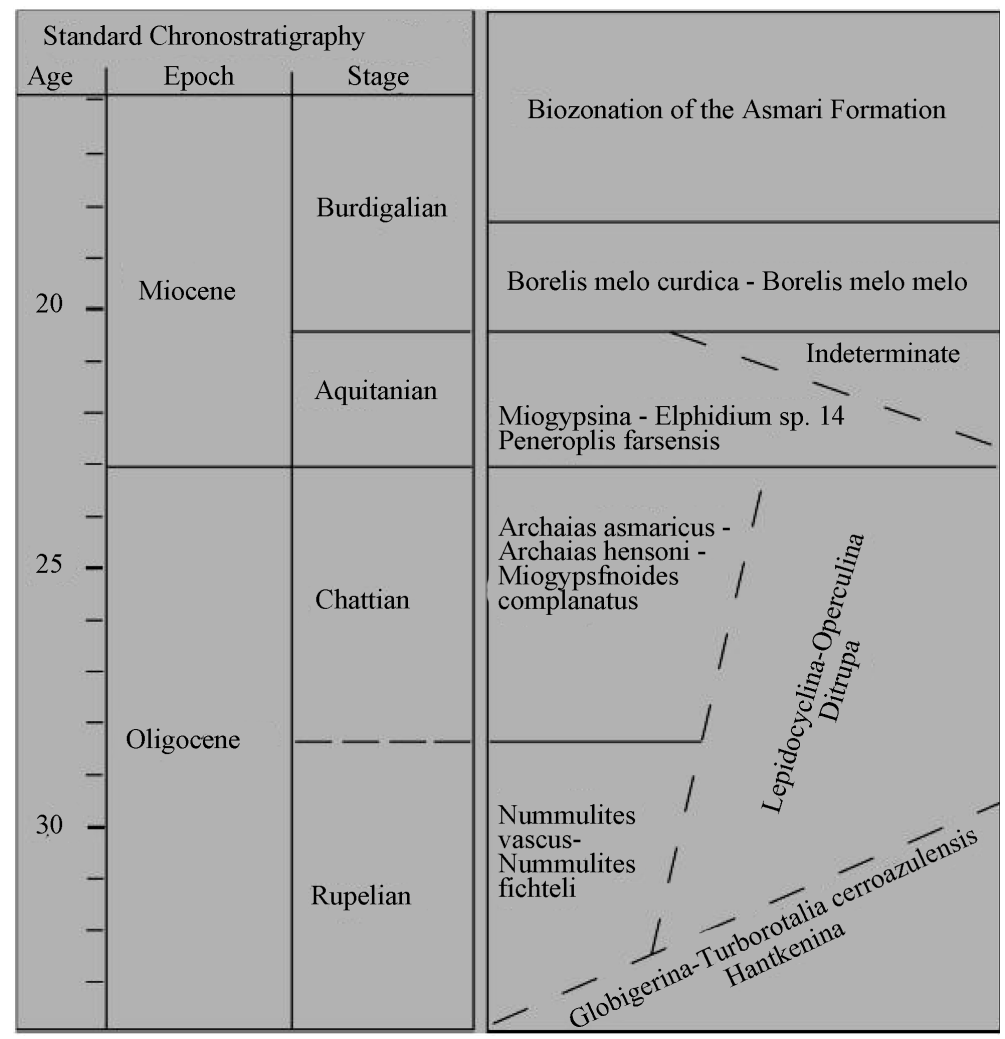

Figure 5. Biozonation of Asmari [6]. 


\subsection{Assemblage Zone 1}

Aged chattian, it is observed in the Sheykh Makan Section (north of Kabir Kuh) and can be correlated with Lepidocyclina-Operculina-Ditrupa assemblage zone The most notable foraminifera are mentioned in the following: Eulepidina sp., Lepidocyclina sp., Nephrolepidina sp., Operculina sp., Operculina complanata, Austrotrillina howchini, Austrotrillina asmaricus, Peneroplis sp., Triloculina trigonula, Spiroclypeus blanckenhorni, miliolids and globigerinids. Other components such as mollusca, echinoderm and corals are also detected in this zone.

\subsection{Assemblage Zone 2}

This interval is aged to aquitanian and observed in the Sheykh Makan Section (north of Kabir Kuh). This zone can be correlated with Miogypsina-Elphi- dium sp. 14-Peneroplis farsensis assemblage zone. Presented study documented following foraminifera are for this interval: Miogypsina sp., Elphidium sp. 14, Lepidocyclina sp., Operculina complanata, Austrotrillina sp., Austrotrillina asmaricus, Peneroplis sp., Peneroplis thomasi, Triloculina trigonula, Miogypsinoides sp., Borelis sp., Meandropsina iranica, Meandropsina anahensis, Dendritina rangi, Amphistegina sp., miliolids, Discorbis sp., Valvulinid sp. And Neorotalia viennoti.

\subsection{Assemblage Zone 3}

Is detected in the section and aged to burdigalian can be an equivalent of Borelis melo curdica-Borelis melo melo Ass. Zone presented by [6]. Identified fossils are:Borelis melo curdica, Borelis sp., Peneroplis sp., Neorotalia sp., Elphidium sp., Meandropsina iranica, Dendritina rangi, Dendritina sp., miliolids, Discorbis sp. and globigerinids. The assemblage represents the Borelis melo curdica-Borelis melo melo assemblage. Other components such as mollusca, echinoderm, miliolids, algae and corals are also detected in this zone.

\section{Microfacies and Facies Belts}

Considering the results of microfacies analyses carried out by inspecting thin section, 15 microfacies grouped in 4 facies belts (tidal flat, lagoon, barrier and open marine) (Figure 6 and Figure 7) are documented for Asmari in two sections. Asmari in Sheykh Makan Section covers tidal flat to outer ramp. This facies distribution implicates the deeper condition in Sheykh Makan. These microfacies from land to basin are described in the following:

\subsection{Sandy Limestone (Mf1)}

This microfacies contains quartz clastic debris dispersed in a carbonate background (Figure 6(a)). Quartz grain is in fine sand size. This microfacies is related to intertidal setting and appears suddenly on top of the microfacies deposited in lower part of mid ramp. It is observed in the lower parts of Asmari presenting its lower gradual contact with Pabdeh in Sheykh Makan Area. Similar 


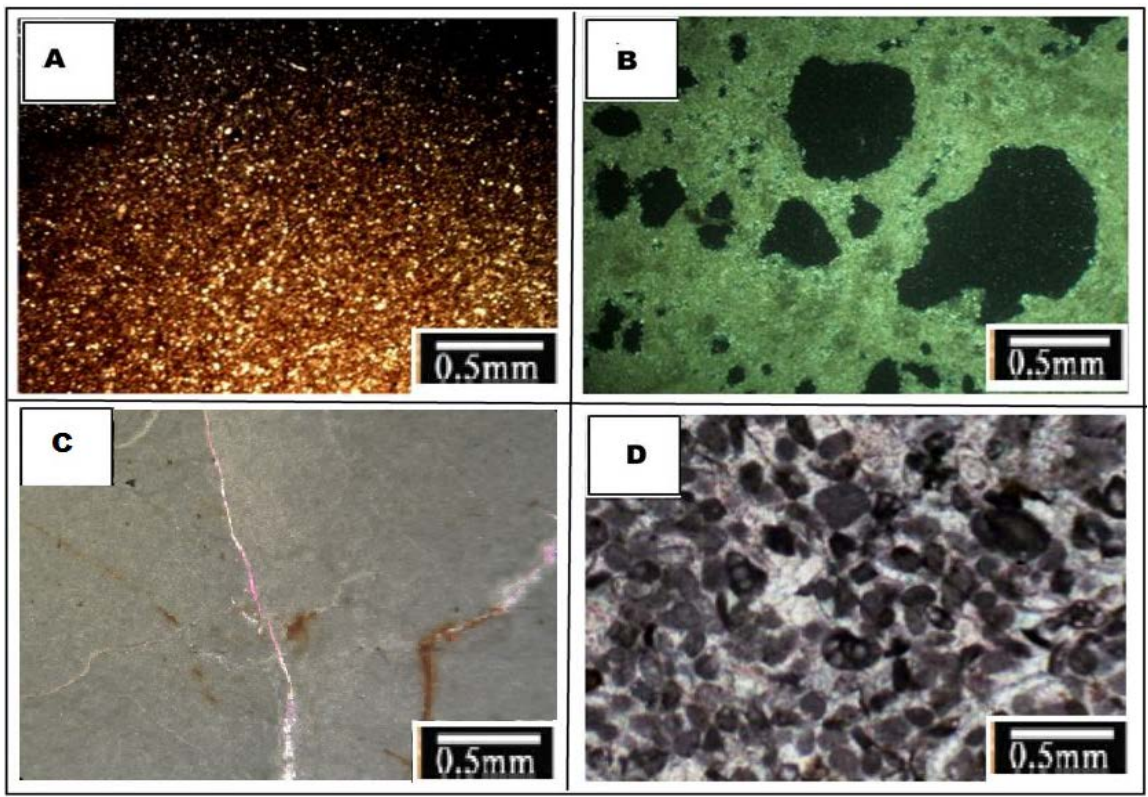

Figure 6. Asmari Formation microfacies in studies sections: (a) Sandy Iimestone; (b) fenestral dolomudstone; (c) Mudstone With the help of gypsum blade; (d) Benthic foraminifera peloids grainstone-packstone.

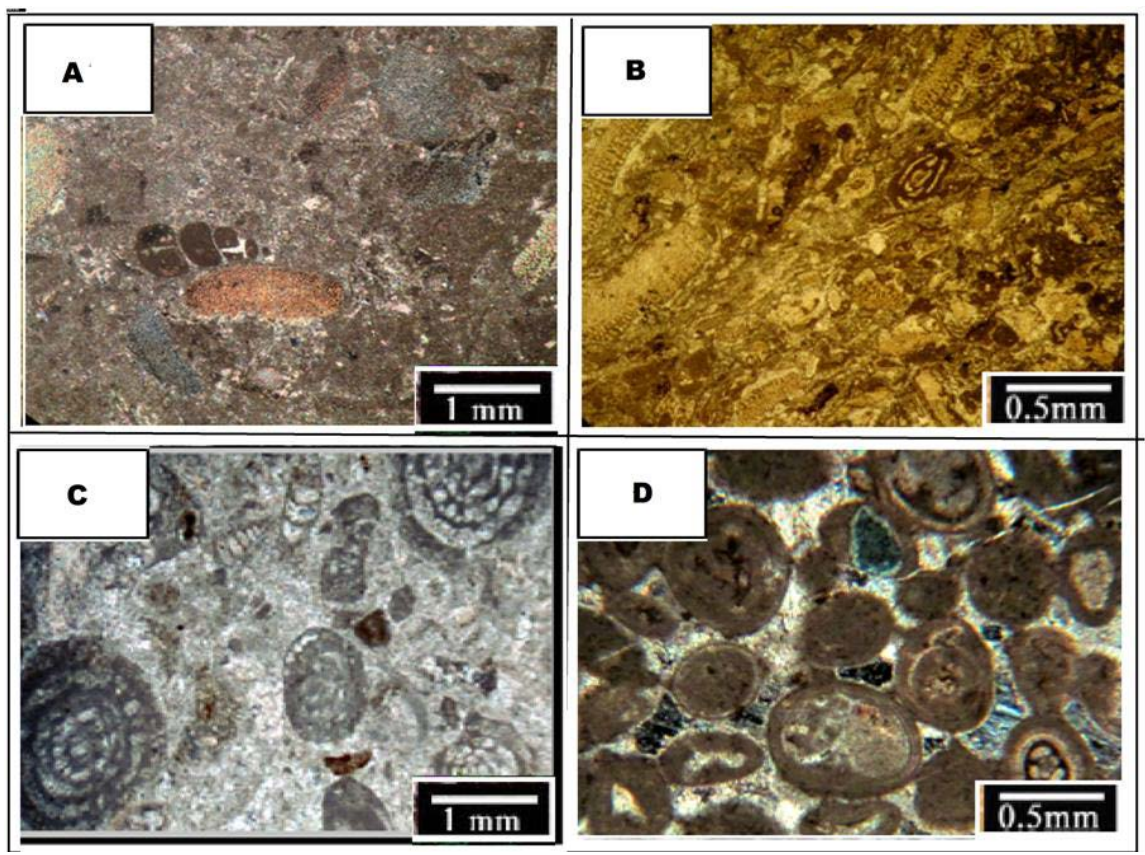

Figure 7. Asmari Formation microfacies in studies sections: (a) Bioclastic Echinoid Wackestone; (b) Bioclastic Echinoid Packstone; (c) Bioclastic high diversity framinifera grainstone-packstone; (d) Bioclastic ooid grainstone

facies are also detected and reported in Dehloran well No. 2 [23] and Tang-eBibi Narjes and Khaviz Anticline [24].

\subsection{Dolomudstone Fenestral (Mf2)}

This microfacies presents fenestral porosity filled with calcite and occasionally 
dolomite and evaporatic cements (Figure 6(b)). Bird's eye or fenestral texture originated from explansion and contraction, gas bubble or escape during flooding and even worms and insects burrowing activities [25]. This ring structure indicates the tidal flat facies belt. Tidal flat is a part of environment orderly or randomly influenced by tidal currents. This facies coexistence with lagoon ones proposes it is formed under effect of tidal currents that is observed and confirmed in the recent environments.

\subsection{Mudstone (Mf3)}

This microfacies is mud-supported and in some samples lamination, microbial and algal textures, evaporatic crystals and quartz grains are observed that all propose it is formed close to shoreline where clastic debris are entered from terrestrial realm (Figure 6(c)). Carbonate mud abundance and deficit of fossil content confirms the lagoon adjacency to shoreline. Negligible abundance and variety of benthic organism is caused by the unfavourable life condition and also the salinity factor. Generally, these sediments are a reliable depth (i.e. relative sea level changes) index, so they can be exerted as an efficient parametere in sequence stratigraphy studies [26] and [27] in Tang-e-Gargadan, [28] in Khaviz Anticline, [29] in Dill Anticline and [30] reported similar microfacies in the Fars Platform and other parts of the Zagros.

\subsection{Benthic Foraminifera Peloids Grainstone-Packstone (Mf4)}

Peloid and Benthic foraminifera such as miliolid and Dendritina are major constituents of this microfacies (Figure 6(d)). Lack of open marine fauna in MF4 declares that it is deposited in lagoon. Foraminifera with porcelaneous test (miliolid) shows existence of light in the depositional zone of this facies (i.e. it is formed in photic zone) [31] [32] [33] and [34]. Detected cementation proposes the notable level of energy in the shoreline part of lagoon. MF-4 is regared as equivalent of RMF 20 designated to laggon. [35] in the Chaman Bolbol Area of Fars and also distinguished similar microfacies from the Asmari Formation.

\subsection{Bioclastic Echinoderm Wackestone-Packstone (Mf5)}

Echinoderm like crinoid and echinoid are the dominant elements of this microfacies. Besides, other allochems such as oyster bivalve, gastropod, benthic foraminifera having porcelaneous test such as miliolid, discorbis, ostracoda, small rotalia and fine string of peyssonneliaceae corals are recorded as minor constituents (Figure 7(a) and Figure 7(b)). Fine clastic quartz grains are randomly dispersed in some samples. Because of the coexistence with lagoon microfacies, it seems MF 5 is deposited in the shoreline front (shallow part) of lagoon.

\subsection{Bioclastic High Diversity Framinifera Grainstone-Packstone (Mf6)}

Benthic foraminifera with porcelaneous test are the most abundant constituent of this microfacies and have considerabe variety. They include miliolid, borelis, 
pygro, schlumbergerina, triloculina, peneroplis, archaias, discorbis, amphistegina, ammonia, faverina, rotalia, dendritina, mindropsina, austrotrillina. Minor constituents in the studied thin section slides are echinoderm, gastropod, bivalve and red algae debris, ostracoda, bryozoa, and peloid (Figure $7(\mathrm{c})$ ). Skeletal fauna related to semi-restricted marine environment including foraminifera with porcelaneous test and grainstone texture both are signatures confirming MF 8 can be deposited in the barrier facies belt that has high levels of energy (a zone shallower than fair weather wave base (FWWB)). Calcareous mud and cement existence acting as orthochems shows the energy fluctuation. This microfacies is found in both the sections and correlates with RMF 27 Similar microfacies are reported in Tang-e-Gargadan [35] and in Tang-e-Bibi Narjes and Tang-e-Aboulfars of Fars for Asmari.

\subsection{Bioclastic Ooid Grainstone (Mf7)}

Ooid is the dominant component of this microfacies. Ooids are uni or multilayered and have good sorting. Compaction influenced the grains and they have point (meniscus cement) or tangent contact in an anhydrite sparitic cemented background. Minor allochems consist miliolid, dendritina, bivalves, bryozoa, faverina, ostracoda, echinoderm, and red algae. Miliolid, dendritina and echinoderm are playing as the most of ooids' nucli (Figure 7(d)). In some slides, ooids are micritized, also lost the primary texture and deformed to peloid. Grainstone texture, ooids, marine cement, transform relicts and good sorting altogether propose high levels of energy existed in the depositional setting of MF 7. Ooids can be formed in a wide range of recent carbonate environment. The most favourable condition is hypersaline shallow (less than 2 meters) enegentic environments with warm weather and high saturation of calcium carbonate [36]. This microfacies is considered as an equivalent of RMF 29 [37] [38] and [39] named almost the same microfacies to MF 7 for Asmari.

\subsection{Peloids Faverina Grainstone-Packstone (Mf8)}

Faverina observed in cross, longitudinal and oblique sections with cemented background is the main allochem of this microfacies. Peloid and corallinaceae red algae are also detected in less frequency (Figure 8(a)). Peloids are possibly faverina fossils crushed by the wave currents. It is mostly observed with ooid grainstone microfacies. This microfacies is known comparable to RMF 27 and shows mid and inner ramp boundaries. Faverina is a fecal pellet produced by a marine crab and reported from Mesozoic shallow limestone, Jurassic sandy limestone and Cretaceous stricted lagoon This facies is also addressed in lower cretaceous Germany sediments formed in the lagoon environment influenced repeatedly by storm microfacies are also reported in other parts of Zagros Tang-e-Band, Tang-e-Aboulfars and Tang-e-Nayab [40] [41] [42].

\subsection{Coral Boundstone (Mf9)}

Coral colonies forming in especial environmental condition are the main com- 
ponent. Corals skeletons has a meander microfabric and pore space is occupied by sparite and micrite [43]. In the field observation, this microfacies clearly detectable with naked eyes by its light gray colour and stone debris. In carbonate ramps, coral structures are formed patch shaped in different locations such as mid and inner ramp [43] Corallinaceae red algae, fine hyaline foraminifera, ostracoda debris, equinoderm, discorbis, ooid, bryozoa and sponge needles are less abundant elements (Figure 8(b)). Discussed microfacies are found between algal (lower interval) and ooid (upper interval) facies indicating MF 9 is formed around the mid and inner ramp boundaries. It can be correlated to RMF 12 Similar microfacies are also reported in Fars by some authors and also other parts of the world its equvalents are documented [44] [45].

\subsection{Benthic Foraminifera Peyssoneliacean Boundstone (Mf10)}

The microfacies with limited lateral extension is in the upper part of the Sekonj section (Figure 9). The main components of the microfacies are only corals (Figure 9). In the field observations, this microfacies is characterized by gray to cream-colored, medium-bedded limestone. Also, small amounts of other bioclasts can be seen in the microfacies. The micritic cements have filled most of the porosity and cavities in the corals. The microfacies are association with Mf9 microfacies in the facies column and its limited extension in the field observations represents deposition as patch reefs in the lagoon toward the carbonate barrier and open marine. The boundstone is interpreted to be formed above the fairweather wave base and in a high energy environment which the autochthonous carbonate are formed and based on the occurrence of coral boundstone facies

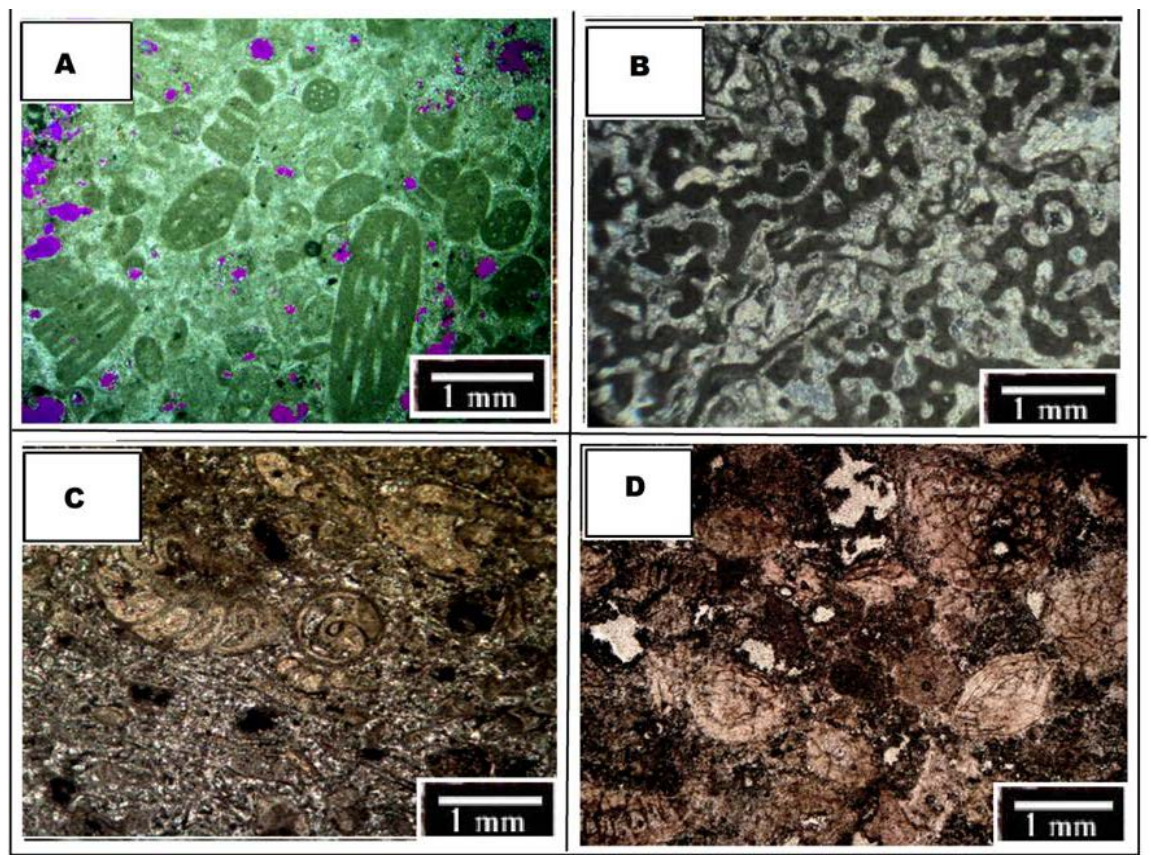

Figure 8. Asmari Formation microfacies in studies sections: (a) Peloids Faverina Grainstone-Packstone; (b) Coral Boundstone; (c) Benthic foraminifera peyssoneliacean boundstone; (d) Corallinacean echinoids miogypsina packstone. 


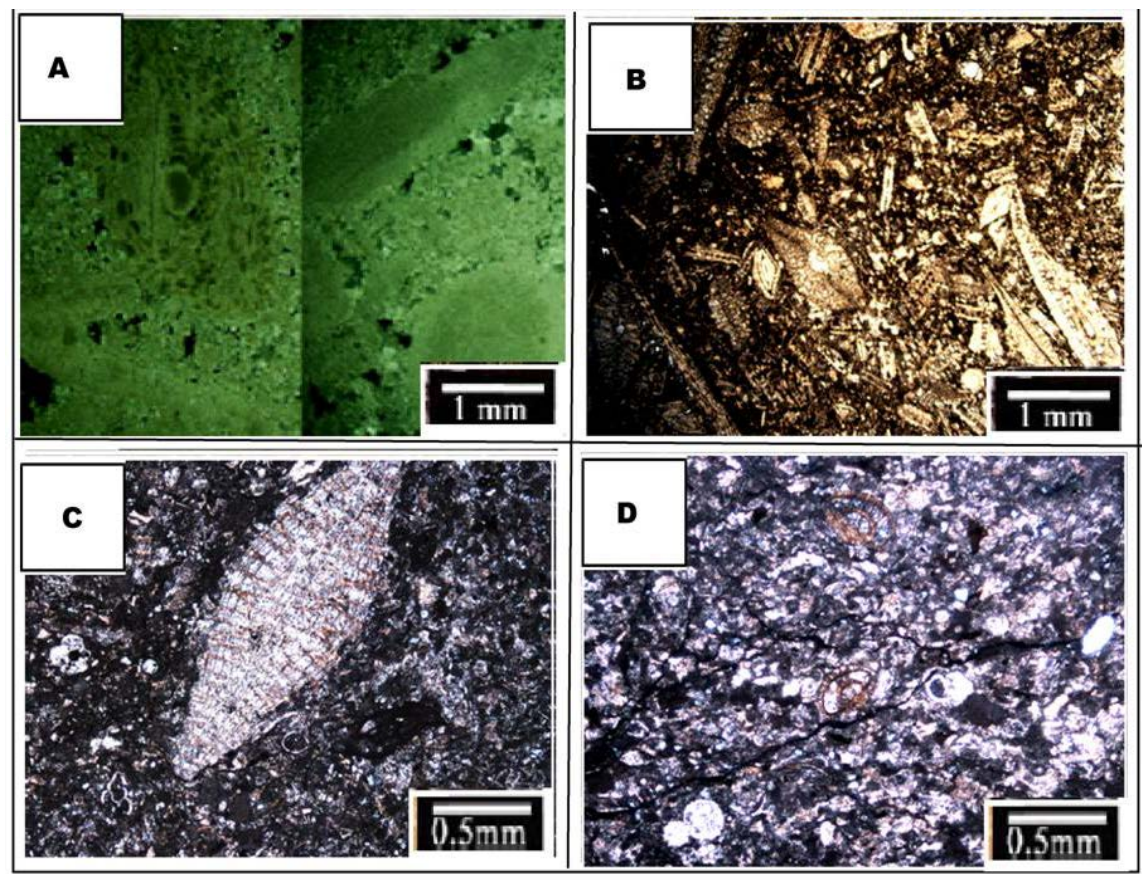

Figure 9. Asmari Formation microfacies in studies sections: (a) Echinoids nummulites corallinacean wackestone-packstone; (b) Bioclastic nummulitidae lepidocyclynidae packstone-floatstone; (c) Planktonic foraminifera lepidocyclinidae nummulitidae bioclastic wackestone-packstone; (d) Planktonic foraminifera bioclastic wackstone-packstone.

suggests a high energy barrier environment.

\subsection{Corallinacean Echinoids Miogypsina Packstone (Mf11)}

Crinoid and large foraminifera such as miogypsina and coralinase red algae are the most abundant components (Figure 8(d)). It is deposited in the open system environment (no restriction) having normal salinity and moderate water flow condirion. Stratigraphic position and marine skeletal fauna confirm the proposed environment for MF 13 and [46]. In some samples echinoderm is more abundant than miogypsina, so the microfacies name can be modified to corallinacean miogypsina echinoderm packstone. It is an equivalent of RMF 27.

\subsection{Echinoids Nummulites Corallinacean Wackestone-PACKSTONE (Mf12)}

Large foraminifera like nummolites, corallinacean red algae are main componenets while minor ones include lepidocyclina, coral and occasionaly porcelaneous foraminifera (Figure 9(a)). Red algae and large foraminifera indicate the deposition of this microfacies in oligophitic realm [47] [48]. Sediments enriched with nummulite and lepidocyclina are lenticular and round. They usually form in shallower setting than sediments having large and prolate ones [49]. Stratigraphic position and marine skeletal fauna (echinoid and red algae) confirms the interpretation presented for depositional environment of MF 12. It can be equal of RMF 7 located at mid ramp. Almost similar microfacies are revealed in other parts of Zagros. 


\subsection{Bioclastic Nummulitidae Lepidocyclynidae Packstone-Floatstone (Mf13)}

The microfacies are mainly composed of large foraminifera with hyaline test. Prolate lepidocyclina is found to be main constituent. Other elements are perculina, heterostegina, red algae, briozoa and echinoid. In some samples the texture is changing to packstone (Figure 9(b)). Lepidocyclina are prolate because in the hyalines coexisting with algae, more light transpasses the shell for reaching to be provided for algae photosynthesis. Then, carbonate severe secretion for generating enough $\mathrm{CO}_{2}$ is used to compensate pervasive photosynthesis and results in the formation these huge shells [50]. Corrallinacea alga and large benthic foraminifera both are indicators for mid ramp facies belt High diversity of prolate and completely saved nummulits and lepicyclina in a micrited texture indocates an open marine condition with low to medium energy and deeper the FWWB. Therefore, large benthic foraminifera abundance, echinoid, and also red algae all confirm that MF 13 is deposited in oligophotic mid ramp [51] [52] [53]. Similar microfacies of Asmari are reported in other parts of the Zagros Region [54].

\subsection{Planktonic Foraminifera Lepidocyclinidae Nummulitidae Bioclastic Wackestone-Packstone (Mf14)}

Prolate large benthic foraminifera such as lepidocyclina and nummulites besides other fauna such as ditropa, echinoderm debris, red algae, bryozoa, planktonic foraminifera (globigerina and globotruncana) and calcisphere and also nonskeletal grains like peloid are the main elements of this microfacies (Figure $9(C))$. Abundance of fauna living in normal salinity like hyaline tested large foraminifera and also planktonic ones implicate the deposition in lower parts of the mid ramp and close to FWWB boundary with storm wave base (SWB). The same MFs are also addressed in other parts of the Zagros Region for Asmari.

\subsection{Planktonic Foraminifera Bioclastic Wackstone-Packstone (Mf15)}

Main allochems are planktonic foraminifera, globigerina and globotruncana without geel, calcisphere, red algae and echinoderm debris while less frequent ones are ditropa, peloid bryozoa and benthic foraminifera debris dispersed in a micritic texture (Figure $8(\mathrm{~d})$ ). This microfacies is detected in the gradual contact of Asmari with Pabdeh. Planktonic foraminifera abundance and mud texture implicate the MF 15 is formed in low energy condition below the SWB. Planktonic microfacies are composed of planktons living in the deeper parts of the basin. The abundance and variety of planktonic fauna of this microfacies confirms its formation in outer ramp setting MF 15 is similar to RMF 5 introduced. The same microfacies existing in the lower parts of Asmari are reported in other zones of the Zagros.

\section{Depositional Model}

Regarding evidence such as absence of reef building facies, transitional changes 
of microfacies from shoreline to deeper zones (outer ramp), lack of shallow belts fossils mixing with deeper ones (mainly observed in rimmed shelf and, depositional setting of the Asmari Formation is distinguished as a carbonate ramp (Figure 10). Meanwhile, absence of breccia, mass flow and turbidite in deep parts of the basin, introduced ramp as a homoclinal one. Asmari has a gradual boundary with Pabdeh in lower contact and this section lithological units are deposited in the deeper settings with marn to marn limestone lithology and planktonic fauna of outer ramp. Upper parts of the Asmari Formation is formed in shallower mid to inner ramp setting. Finally, regression occurred and evaporitic Gachsaran succession emerged on top of the Asmari. Analogous environments can be found in Persian Gulf.

\section{Sequence Stratigraphy}

To specify depositional sequences, maximum floding surface (MFS) and sequence boundary (SB) are applied. These interpretations are foremerly exerted by authors such as [55] [56] [57] [58] [59]. In Sheykh Makan three shallowing up and in Asman Dul an aggressive sequence and a shallowing up are characterized.

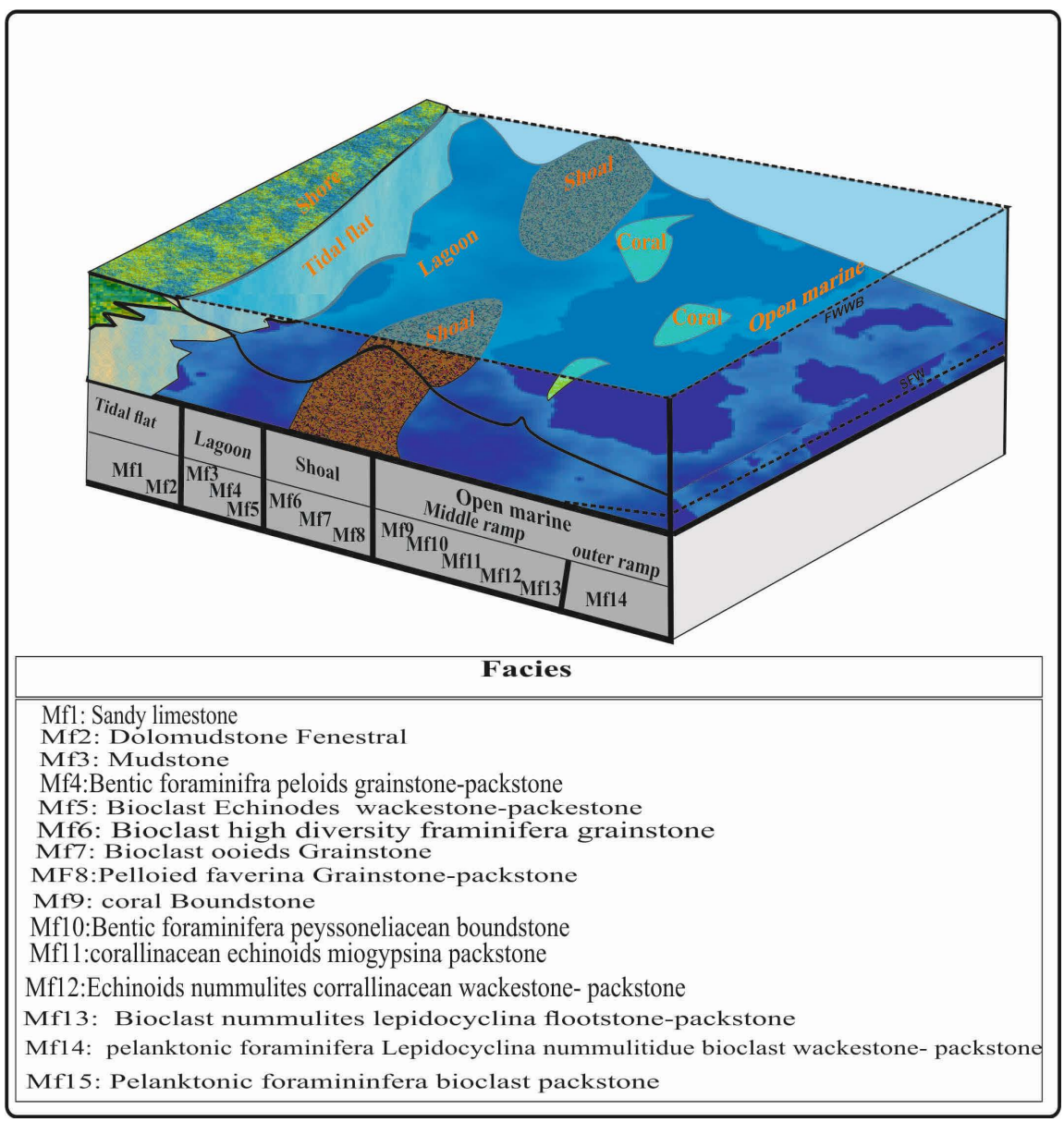

Figure 10. Conceptual depositional model of the Asmari Formation in Shekh Makan section located at Lurestan Basin. 


\subsection{Sequence 1}

This sequence is noted only in Sheykh Makan Section, including a 34.5 meters highstand system tract (HST) aged late chattian - early achitanian. The sequence lithology is marny limestone (argillaceous limestone) and marn. It covers the upper parts of the Pabdeh Formation and lower zone of Asmari. The succession is formed as a shallowing up complex, starting with shale and marn and continuing with microfacies belonging to mid and outer ramp facies belts. Finally, a 1 meter sandy limestone formed in tidal flat (MF 2) caps lower mid ramp facies. As mentioned, MF 2 deciphers a firced regression and plays the rule of SB. Inspecting the microfacies from base to top of this sequence, a shallowing up trend is acquired.

\subsection{Sequence 2}

In Sheykh Makan, it is 112 meters and contains three system tracts: lowstand system tracts (LST), HST and transgressive system tract (TST) aged to achitanian. Lower boundary sits on the sandy limestone layer deposited in the tidal flat (forced regression). Bellow this layer, shallowing up trend is clearly observable, whereas deepening up trend is formed above it. Lagoon carbonate succession covers MF 2 and deciphers the relative sea level rise resulted in carbonates deposition.

About upper parts of this sequence, thick to medium layered limestone succession deposited in deep parts of the mid ramp is distiguished. MF 16 is the deepest microfacies of sequence 2, so picked as the MFS. Transgression of this sequence is deciphered observing evidence such as stratigraphic position of deposits in upper parts, revealed MFS, and existence of shallowing up succession (HST) on upper interval. Sequence 2 is an analogous to type 1a. 93.5 meters of shallowing up carbonate interval (HST) composed of mid ramp sediments (patch reef, then barrier and finally lagoon) covers discussed TST.

\subsection{Sequence 3}

This sequence is also found in both evaluated section. It is 54 meters and include TST and HST (shallowing up trend) in Sheykh Makan Section. Its age is late achitanin to burdigalian. SB 2 is revealed as the lower contact of this sequence. The TST presents a gradual deepening up trend from laggon and barrier facies belts toward coral patch reefs (MF11). This unit resembles type 1b TST introduced by Tucker et al., 1993. Upper parts of this sequence have aggradaing carbonate succession deposited in barrier and lagoon setting caped with tidal flat facies (indicator of SB1), implicating a shallowing up trend (i.e. HST). Evaporatic Gachsaran Formation is observed in the top of this boundary in field patrol. Third sequence in Asman Dul Section is about 56 meters and includes LST and HST. In fact, it merely covers the upper Asmari Formation, so aged burdigalian. Two sequence boundaries exist at the top and base of this sequence. The lower SB is picked where the conglomerate layer emerges (1.5 meters), implicationg the pervasive regression. The upper SB separates the evaporatic Gachsaran 
Froramtion from Asmari. This complex shows a clear shallowing up trend.

\section{Comparing Studied Sections Sequences to Arabian Plate (Hag et al., 2005) and Global Sequences (Ogg et al., 2016)}

Relative sea level changes curve provided for Sheykh Makan Section is in great accordance with Arabian Plate sequences. In this section, upper and lower contacts of the sequences can be correlated with global sea level fall, but the sequences are different from globals that possibly originates from internal tectonic processes (Figure 11).

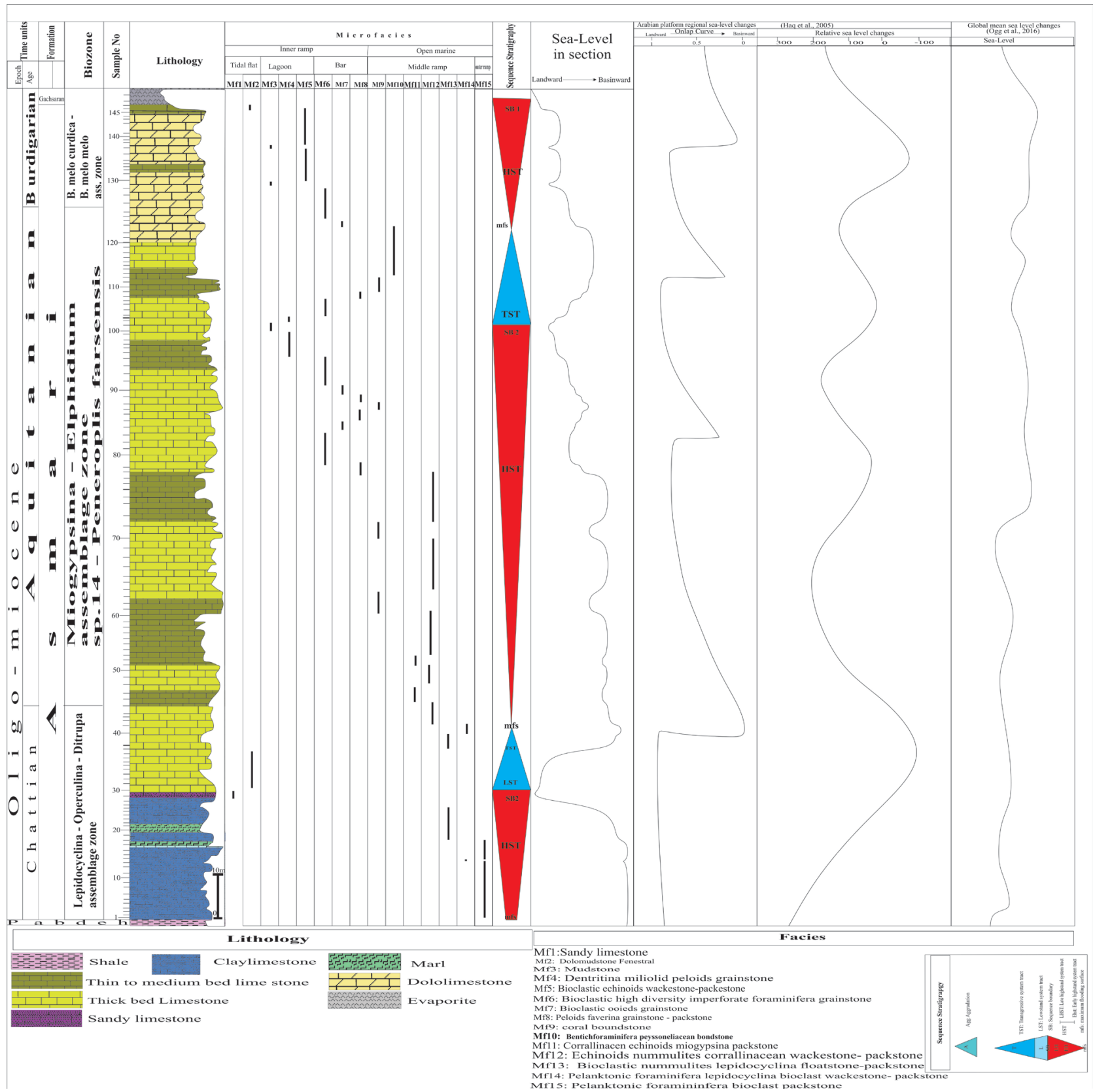

Figure 11. Lithstratigraphic, facies, sequence stratigraphic column of Asmari in Sheykh Makan Section compared to Arabian Plate [21] and global [22] sequences. 
Peyssoneliacea boundstone microfacies detected in third sequence of Sheykh Makan indicate its difference from the other studied section. The first section is surely influenced by regional tectonic that prepared the especial favourable life condition needed for this rare coral. This property has made this area unique. Regarding this comparison, it is clearly understood that factors beside the eustasy controlled Asmari facies distribution. The global factor influence Asmari generally, but small scale changes in sequences are caused by regional and local ones. Tectonic movement in Zagros Region can be addressed as the most influential factor resulting in Sheykh Makan difference. The movements finally led to closure of neotethys and generation of foreland basin. Evidence of tectonic activity that tectonic parameter played the most dominant role in accommodation space changes of Zagros Basin while eustasy has merely influenced the formation of stratigraphic geometries. It seems movements finally closed the basin (i.e. followed by subduction and collision).

\section{Conclusions}

Results of this study revealed 15 microfacies, can be determined for Asmari in Sheykh Makan section. Thick ooid grainstone facies indicates the ramp depositional setting and other evidence such as transitional change of facies and lack of turbidite facies also confirm the existence of a homoclinal ramp in the studied time range for both the section. In the Sheykh Makan Section, inner, mid and outer ramp facies are deposited. Frequency of deeper facies in the first section proposes that deeper basin existed in southern parts of Zagros.

Asmari is covered by evaporatic Gachsaran Formation in this section. In Sheykh Makan, Asmari overlies shale bearing Pabdeh gradually. Sequence stratigraphic analyses resulted in characterizing three third order sequences in Sheykh Makan: an incomplete sequence in Pabdeh and two complete shallowing up ones in Asmari.

Asmari is aged oligomiocene and contains lower (chattian), middle (achitanian) and upper (burdigalian) units. The third sequence of Asmari in Sheykh Makan is totally different from the first one. Peyssoneliacea boundstone substituted coral red algae facies in this sequence. Relative sea level changes curve provided for Sheykh Makan Section is in great accordance with Arabian Plate sequences. In this section, upper and lower contacts of the sequences can be correlated with global sea level fall. But the sequences are different from globals that possibly originates from internal tectonic processes. Tectonic activities closed the neotethys are the most probable factor causing this unique property.

\section{References}

[1] Motiei, H. (2001) Simplified Table of Rock Units in Southwest Iran: Tehran, Keyhan Exploration and Production Services.

[2] Busk, H.G. and Mayo, H.T. (1918) Some Notes on the Geology of the Persian Oil Fields. Institution of Petroleum Technologists, 5, 5-26.

[3] Wynd, J. (1965) Biofacies of Iranian Oil Consortium Agreement Area. IOOC Report 1082, Unpublished. 
[4] Adams, T.D. and Bourgeois, F. (1967) Asmari Biostratigraphy. Unpublished Report 1074, Iranian Oil Operating Companies, Geology and Exploration Division, Tehran.

[5] Ehrenberg, S.N., Pickard, N.A.H., Laursen, G.V., Monibi, S., Mossadegh, Z.K., Svånå, T.A., Aqrawi, A.A.M. and Thirlwall, J.M.M.M.F. (2007) Strontium Isotope Stratigraphy of the Asmari Formation (Oligocene-Lower Miocene) SW Iran. Journal of Petroleum Geology, 30, 107-128. https://doi.org/10.1111/j.1747-5457.2007.00107.x

[6] Laursen, G.V., Monibi, S., Allan, T.L., Pickard, N.A., Hosseiney, A., Vincent, B., Hamon, Y., Van-Buchem, F.S.P., Moallemi, A. and Druillion, G. (2009) The Asmari Formation Revisited: Changed Stratigraphic Allocation and New Biozonation: Shiraz. 1 st International Petroleum Conference and Exhibition, European.

[7] Schlager, W. (2005) Carbonate Sedimentology and Sequence Stratigraphy. No. 8, SEPM Soc for Sed Geology. https://doi.org/10.2110/csp.05.08

[8] Ahr, W.M. (2008) Geology of Carbonate Reservoir. John Wiley and Sons, Hoboken, 277 p. https://doi.org/10.1002/9780470370650

[9] Mehrabi, H., Rahimpour-Bonab, H., Enayati-Bidgoli, A.H. and Esrafili-Dizaji, B. (2015) Impact of Contrasting Paleoclimate on Carbonate Reservoir Architecture: Cases from Arid Permo-Triassic and Humid Cretaceous Platforms in the South and Southwestern Iran. Journal of Petroleum Science and Engineering, 126, 262-283.

[10] Posamentier, H.W. and Vail, P.R. (1988) Eustatic Controls on Clastic Deposition II-Sequence and Systems Tract Models.

[11] Van Wagoner, J.C., Mitchum, R.M., Campion, K.M. and Rahmanian, V.D. (1990) Siliciclastic Sequence Stratigraphy in Well Logs, Cores, and Outcrops: Concepts for High-Resolution Correlation of Time and Facies.

[12] Posamentier, H.W. and Allen, G.P. (1999) Siliciclastic Sequence Stratigraphy: Concepts and Applications. Vol. 7, SEPM (Society for Sedimentary Geology), Tulsa. https://doi.org/10.2110/csp.99.07

[13] Aghanabati, A. (2004) Geology of Iran. Geological Survey of Iran.

[14] Darvishzadeh, A. (1991) Geology of Iran. Neda Publication, Tehran, 1-901.

[15] Sharland, P.R., Archer, R., Casey, D.M., Davies, R.B., Hall, S.H., Heward, A.P., Horbury, A.D. and Simmons, M.D. (2001) Arabian Plate Sequence Stratigraphy. GeoArabia, Special Publication 2, Bahrain, 371 p.

[16] Stocklin, J. (1968) Structural History and Tectonics of Iran; A Review. American Association of Petroleum Geologist Bulletin, 52, 1229-1258.

[17] Motiei, H. (2003) Stratigraphy of Zagros. Geological Survey and Mineral Exploration of Iran, Book, No. 84, 636 p.

[18] Embry, A.F. and Klovan, J.E. (1971) A Late Devonian Reef Tract on Northeastern Banks Island, Northwest Territories. Bulletin of Canadian Petroleum Geology, 19 , 730-781.

[19] Dunham, R.J. (1962) Classification of Carbonate Rocks According to Depositional Texture. American Association of Petroleum Geologists, 1, 108-121.

[20] Flugel, E. (2010) Microfacies of Carbonate Rocks, Analysis, Interpretation and Application. Springer-Verlag, Berlin, $976 \mathrm{p}$.

[21] Haq, B.U. and Al-Qahtani, V. (2005) Jurassic-Neogene Arabian Platform Cycle Chart. GeoArabia, 10, 34 p.

[22] Ogg, J.G., Ogg, G.M. and Gradstein, F.M. (2016) A Concise Geologic Time Scale. Elsevier, $229 \mathrm{p}$

[23] Seyrafian, A., Arzani, A., Taheri, H., Vaziri-Moghaddam, H. and Hashemi (2006) 
The Final Report of the Research Project Facies Asmari on the Hills of West North West Zagros (Dehloran-Khorram Abad Changooleh) Company National Iranian oil Research and Technology.

[24] Rahmani, A., Taheri, A., Vaziri-Moghaddam, H. and Ghabeishavi, A. (2011) Biostratigraphy of the Asmari Formation at Khaviz and Bangestan Anticlines, Zagros Basin, SW Iran. Neues Jahrbuch für Geologie und Paläontologie.

[25] Shinn, E. (1983) Tidal Flats. In: Scholle, P.A., Bebout, D.G. and Moore, C.H., Eds., Carbonate Depositional Environments: American.

[26] Vaziri-Moghaddam, H., Kimiagari, M. and Taheri, A. (2006) Depositional Environment and Sequence Stratigraphy of the Oligocene-Miocene Asmari Formation in SW Iran, Lali Area. Facies, 52, 41-51. https://doi.org/10.1007/s10347-005-0018-0

[27] Amirshahkarami, M., Vaziri-Moghaddam, H. and Taheri, A. (2007) Sedimentary Facies and Sequence Stratigraphy of the Asmari Formation Chaman-Bolbol, Zagros Basin, Iran. Journal of Asian Earth Science, 29, 947-959.

[28] Rahmani, A., Vaziri-Moghaddam, H., Taheri, A. and Ghabeishavi, A. (2009) Amodel for the Paleoenvironmental Distribution of Larger Foraminifera of OligoceneMiocene Carbonate Rocks at Khaviz Anticline, Zagros Basin, SW Iran. Historical Biology, 21, 215-227. https://doi.org/10.1080/08912960903461296

[29] Allahkarampour Dill, M., Seyrafian, A. and Vaziri-Moghaddam, H. (2010) Asmari Formation, North of the Gachsaran (Dill Anticline) Southwest Iran: Facies Analysis, Depositional Environments and Sequence Stratigraphy.

[30] Sadeghi, R., Vaziri-Moghaddam, H. and Taheri, A. (2010) Microfacies and Sedimentary Environment of the Oligocene Sequence (Asmari Formation Moghaddam, H., 2011. Biostratigraphy and Paleo-Ecological Implications in Microfacies of the Asmari Formation (Oligocene) Naura Anticline (Interior Fars of the Zagros Basin) Iran. Carbonates Evaporites, 26, 167-180.

[31] Wilson, J.L. (1975) Carbonate Facies in Geologic History. Springer-Verlag, Berlin, 471 p. https://doi.org/10.1007/978-1-4612-6383-8

[32] Pedley, M. (1996) Miocene Reefs Distributions and Their Associations in the Central Mediterranean Region: An Overview. In: Franseen, E., Esteban, M., Ward, W.C. and Rouchy, J.M., Eds., Models for Carbonate Stratigraphy from Miocene Reef Complexes of the Mediterranean Regions, Soc. Econ. Paleont. Miner., Concepts in Sedimentology and Paleontology Series, 5, 73-87. https://doi.org/10.2110/csp.96.01.0073

[33] Geel, T. (2000) Recognition of Stratigraphic Sequences in Carbonate Platform and Slope Deposits, Empirical Models Based on Microfacies Analysis of Palaeogene Deposits in Southeastern Spain. Palaeogeography, Palaeoclimatology, Palaeoecology, 155, 211-238.

[34] Romero, J., Caus, E. and Rossel, J. (2002) A Model for the Palaeoenvironmental Distribution of Larger Foraminifera Based on Late Middle Eocene Deposits on the Margin of the South Pyrenean Basin. Palaeogeography Palaeoclimatology Palaeoecology, 179, 43-56.

[35] Shabafrooz, R., Mahboubi, A., Moghaddam, H., Ghabeishavi, A. and MoussaviHarami, R. (2015) Depositional Architecture and Sequence Stratigraphy of the OligoMiocene Asmari Platform; Southeastern Izeh Zone, Zagros Basin, Iran. Facies, 61, 423.

[36] Lees, A. (1975) Possible Influence of Salinity and Temperature on Modern Shelf Carbonate Sedimentation. Marine Geology, 19, 159-198.

[37] Vaziri-Moghaddam, H., Seyrafian A., Taheri, A. and Motiei, H. (2010) OligoceneMiocene Ramp System (Asmari Formation) in the NW of the Iran. 
[38] Moghaddam, H. (2010) The Asmari Formation, North of the Gachsaran (Dill Anticline) Southwest Iran: Facies Analysis, Depositional-Environments and Sequence Stratigraphy. Carbonates and Evaporites, 25, 145-160. https://doi.org/10.1007/s13146-010-0021-6

[39] Daniel, J.M., Nader, F., Hamon, J.Y. and Callot, J.P. (2008) Asmari Reservoir Modeling-Field Scale Study of Gachsaran-Final Report Part 1. The International IOR Research Cooperation for Iranian Fields, Joint Study Program, Tehran.

[40] Adams, T.D. (1968) Asmari Formation Thickness Maps for Khuzestan and Lurestan, with Stratigraphic Comments, Technical Memo. 49 Tehran, Iranian Oil Operating Companies, Geological and Exploration Division, Unpublished.

[41] Mossadegh, Z.K., Haig, D.W., Allan, T., Adabi, M.H. and Sadeghi, A. (2009) Salinity Changes during Late Oligocene to Early Miocene Asmari Formation Deposition, Zagros Mountains, Iran. Palaeogeography, Palaeoclimatology, Palaeoecology, 272, 17-36.

[42] Van Buchem, F.S.P., Allan, T.L., Laursen, G.V., Lotfpour, M., Moallemi, A.S., Mobini, M., Pickard, H., Tahmasbi, N.A.H., Vedrenne, A.R.N.A.H.V. and Vincent, B. (2010) Regional Stratigraphic Architecture and Reservoir Types of the Oligo-Miocene Deposits in the Dezful Embayment (Asmari and Pabdeh Formations) SW Iran. Geological Society, London, Special Publications, 329, 219-263. https://doi.org/10.1144/SP329.10

[43] Tucker, M.E. and Wright, V.P. (1990) Carbonate Sedimentology. Blackwell, Oxford, 482.

[44] Corda, L. and Brandano, M. (2003) Aphotic Zone Carbonate Production on a Miocene Ramp, Central Apennines, Italy. Sedimentary Geology, 161, 55-70, 56-71.

[45] Wanas, H.A. (2008) Cenomanian Rocks in the Sinai Peninsula, Northeast Egypt: Facies Analysis and Sequence Stratigraphy. Journal of African Earth Sciences, 52, 125-138.

[46] Pomar, L. (2001) Types of Carbonate Platforms: A Genetic Approach. Basin Research, 13, 313-334. https://doi.org/10.1046/j.0950-091x.2001.00152.x

[47] Rasser, M.W. and Nebelsick, J.H. (2003) Provenance Analysis of Oligocene Autochthonous and Allochthonous Coralline Algae: A Quantitative Approach.

[48] Bassi, D., Hottinger, L. and Nebelsick, J.H. (2007) Larger Foraminifera from the Upper Oligocene of the Venetian Area, North-East Italy. Paleontology, 50, 845-868. https://doi.org/10.1111/j.1475-4983.2007.00677.x

[49] Beavington-Penney, S.J. and Racey, A. (2004) Ecology of Extant Nummulitids and Other Larger Benthic Foraminifera: Applications in Paleoenvironmental Analysis. Earth Science Reviews, 67, 219-265.

[50] Hohenegger, J. (1996) Remarks on the Distribution of Larger Foraminifera (Protozoa) from Palau (Western Carolines). In: Aoyama, T., Ed., The Progress Report of the 1995 Survey of the Research Project, Man and the Environment in Micronesia, Kagoshima University Research Center for the Pacific Islands, Occasional Papers, Vol. 32, 19-45.

[51] Nebelsick, J.H., Rasser, M. and Bassi, D. (2005) Facies Dynamic in Eocene to Oligocene Circumalpine Carbonates. Facies, 51, 197-216.

[52] Barattolo, F., Bassi, D. and Romero, R. (2007) Upper Eocene Larger ForaminiferalCoralline Algal Facies from the Klokova Mountain (South Continental Greece). Facies, 53, 361-375. https://doi.org/10.1007/s10347-007-0108-2

[53] Brandano, M., Frezza, V., Tomassetti, L. and Cuffaro, M. (2009) Heterozoan Carbonates in Oligotrophic Tropicalwaters: The Attard Member of the Lower Coralline 
Limestoneformation (Upper Oligocene, Malta). Palaeogeography, Palaeoclimatology, Palaeoecology, 274, 54-63.

[54] Sooltanian, N., Seyrafian, A. and Vaziri-Moghaddam, H. (2011) Biostratigraphy and Paleo-Ecological Implications in Microfacies of the Asmari Formation (Oligocene) Naura Anticline (Interior Fars of the Zagros Basin) Iran. Carbonates Evaporites, 26, 167-180. https://doi.org/10.1007/s13146-011-0053-6

[55] Sarg, J.F. (1988) Carbonate Sequence Stratigraphy. In: Wigus, C.K., Ed., Sea-Level Change: An Integrated Approach, Society of Economic Paleontologists and Mineralogists, Special Publication 42, 155-181. https://doi.org/10.2110/pec.88.01.0155

[56] Van Wagoner, J.C. (1985) Reservoir Facies Distribution as Controlled by Sea-Level Change.

[57] Tucker, M.E., Calvet, F. and Hunt, D. (1993) Sequence Stratigraphy of Carbonate Ramps: System Tracts, Models and Application to the Muschelkalk Carbonate Platforms of Eastern Spain. In: Posamentier, H.W., Summerhayes, C.P., Haq, B.U. and Allen, G.P., Eds., Sequence Stratigraphy and Facies Associations, International Association of Sedimentary Special Publication 18, 397-415.

[58] Emery, D. and Myers, K.J. (1996) Sequence Stratigraphy. Oxford, Blackwell, 297 p. https://doi.org/10.1002/9781444313710

[59] Catuneanu, O. (2006) Principles of Sequence Stratigraphy. Elsevier, Amsterdam, $375 \mathrm{p}$.

Submit or recommend next manuscript to SCIRP and we will provide best service for you:

Accepting pre-submission inquiries through Email, Facebook, LinkedIn, Twitter, etc. A wide selection of journals (inclusive of 9 subjects, more than 200 journals)

Providing 24-hour high-quality service

User-friendly online submission system

Fair and swift peer-review system

Efficient typesetting and proofreading procedure

Display of the result of downloads and visits, as well as the number of cited articles

Maximum dissemination of your research work

Submit your manuscript at: http://papersubmission.scirp.org/

Or contact ojg@scirp.org 